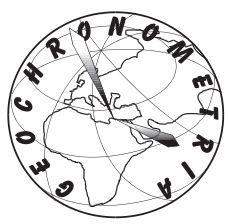

\title{
CHRONOLOGY OF SEAFLOOR MASSIVE SULFIDES FORMATION WITHIN THE POBEDA HYDROTHERMAL CLUSTER (MID-ATLANTIC RIDGE)
}

\author{
V. KUZNETSOV ${ }^{1 *}$, G. CHERKASHOV ${ }^{1,2}$, K. KUKSA ${ }^{1}$, A. FIRSTOVA ${ }^{2}$, F. MAKSIMOV ${ }^{1}$, V. BEL'TENEV ${ }^{3}$, \\ L. LAZAREVA ${ }^{3}$, S. LEVCHENKO ${ }^{1}$, N. BARANOVA $^{1}$ \\ ${ }^{1}$ St. Petersburg State University, Universitetskaya nab., 7-9, St. Petersburg 199034, Russia \\ ${ }^{2}$ Institute for Geology and Mineral Resources of the Ocean (VNIIOkeangeologia), \\ Angliysky Prospect 1, St. Petersburg 190121, Russia \\ ${ }^{3}$ Polar Marine Geosurvey Expedition, Pobedy Str. 24, Lomonosov 198412, St. Petersburg, Russia \\ Received 27th December 2019 Accepted 28th August 2020

\begin{abstract}
A geochronological and mineralogical study on the seafloor massive sulfides from the Pobeda hydrothermal cluster at the Mid-Atlantic Ridge was carried out. To improve the reliability of geochronological data, the $230 \mathrm{Th} / \mathrm{U}$ ages were measured for both the bulk samples and monomineral separates. The oldest age ca. 52 kyr within Pobeda-1 and ca. 107 kyr within Pobeda-2 fields have been obtained. Then, several episodes of hydrothermal activity were identified within both fields up to ca. $0.3 \mathrm{kyr}$ ago and up to ca. $4.3 \mathrm{kyr}$ ago, respectively.
\end{abstract}

Keywords

geochronology, hydrothermal activity, 230Th/U dating, seafloor massive sulfides.

\section{Introduction}

The geochronological study of seafloor massive sulfides (SMS) started at the end of last century when the first ${ }^{230} \mathrm{Th} / \mathrm{U}$ ages of sulfide ores were obtained by Lalou et al. $(1986,1993,1996)$ for the samples from hydrothermal fields at the Mid-Atlantic Ridge (MAR). Since that time, numerous data were obtained by the ${ }^{230} \mathrm{Th} / \mathrm{U},{ }^{210} \mathrm{~Pb}$ and ${ }^{226} \mathrm{Ra} / \mathrm{Ba}$ methods for hydrothermal deposits at the MAR, East Pacific Rise, South-West Indian Ridge and other ridges and Island Arc systems (Lalou et al., 1998; You and Bickle, 1998; Kuznetsov et al., 2006, 2007, 2011, 2015; Kuznetsov and Maksimov, 2012; Wang, 2012; Jamieson et al., 2013; Yang et al., 2017; Cherkashov et al., 2017; Liang et al., 2018). It was shown that the hydrothermal activity and the related ore formation had a pulse pattern marked by a certain number of episodes recurring with time intervals up to several thousand years. However, despite the presence of numerical SMS dates, there is still no general view on the frequency and time span of ore formation, on which the tonnage of SMS deposits is heavily depended.

One of the most important methodological constrains which still remains is that sulfide ores are usually composed by aggregated minerals of a different generation and dating of a bulk sample can disregard the age of individual mineral formation. This sometimes leads to averaging or distorted ages of bulk samples, as clearly demonstrated for TAG deposit (You and Bickle, 1998).

Taking into account this issue, the main aim of this paper is to evaluate chronology of SMS formation for both the bulk samples and monomineral separates from the Pobeda deposit at the Mid-Atlantic Ridge.

\section{Location and Site Description}

The Pobeda hydrothermal sulfide cluster is located on the eastern flank of the MAR rift valley in the range of $17^{\circ} 07.45^{\prime}-17^{\circ} 08.7^{\prime} \mathrm{N}$ (Fig. 1) (Beltenev et al., 2015;

Corresponding author: V. Kuznetsov

e-mail: v.kuznetsov@spbu.ru

ISSN 1897-1695 (online), 1733-8387 (print)

(c) 2020 V. Kuznetsov et al. This work is licensed under the Creative Commons Attribution-NonCommercial-NoDerivatives 3.0 License. 

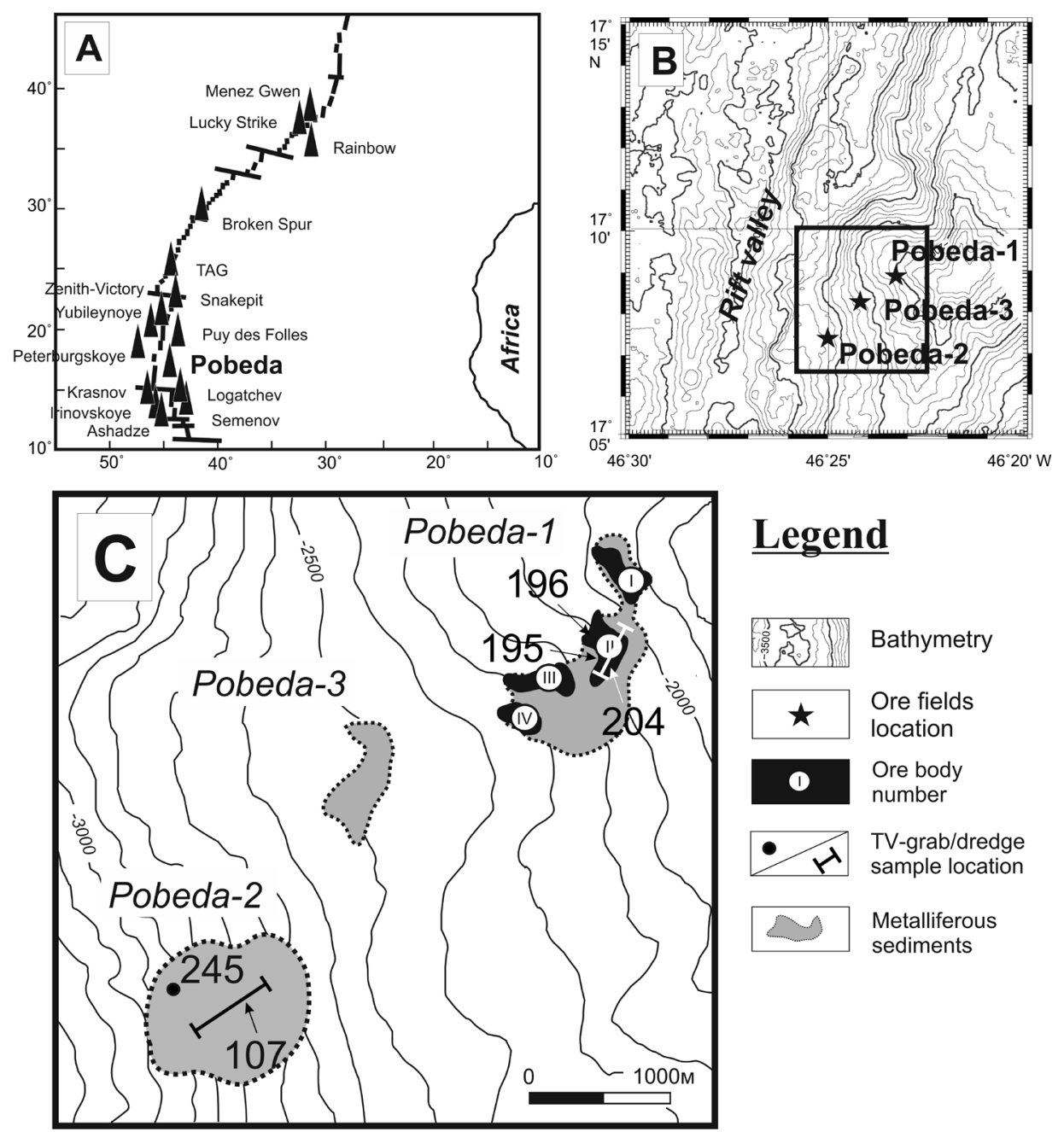

Fig 1. Sketch map of Pobeda sulfide cluster. A - Position of the Pobeda cluster at the Mid-Atlantic Ridge. B-Bathymetric map showing locations of the three fields on an eastern flank of a rift valley. $C$ - Detailed scheme with the sampling stations locations.

Cherkashov et al., 2017). It is related to the uplifted lower crust and upper mantle rocks (oceanic core complex, OCC) of the MAR segment characterized by asymmetric mode of accretion. The OCC is represented by gabbro-peridotite rocks exhumed on the rift valley slope along the detachment fault. The detailed geological description of the Pobeda cluster is given in a number of papers (Beltenev et al., 2015; Cherkashov et al., 2017; Amplieva et al., 2017; Gablina et al., 2018).

The Pobeda hydrothermal cluster includes three sites: the Pobeda- 1 occurs at the depth between 1950 and 2400 $\mathrm{m}$ and consists of four ore bodies up to $10 \mathrm{~m}$ high; the Pobeda-2 is located $4 \mathrm{~km}$ southwest downslope from the Pobeda-1 field at a water depth of between 2800 and 3100 $\mathrm{m}$. The modern hydrothermal activity was revealed by turbidity anomalies in the near-bottom waters and camera-tow visual observations. The hydrothermal mineralization is represented by massive sulfides, sulfide breccias and crusts, ore-bearing sediments and sulfide impregnation in the host rocks (Beltenev et al., 2015; Cherkashov et al., 2017).

\section{Material and analytical methods}

Samples were collected using dredge and a TV-controlled grab during the cruise of R/V "Professor Logatchev" organized by Polar Marine Geosurvey Expedition and VNIIOkeangeologia (St. Petersburg, Russia) in 2014-2015 (Beltenev et al., 2015).

The first data of sample compositions and ${ }^{230} \mathrm{Th} / \mathrm{U}$ ages from Pobeda cluster were obtained for different types of hydrothermal mineralization (massive sulfides, sulfide breccias and ore-bearing sediments) (Gablina et al., 2018). The present study focuses on 14 samples of massive sulfides only as they mark the direct precipitation from the 
high-temperature hydrothermal fluid in contact with seawater and could be better used for reconstruction of the history of hydrothermal activity.

The major and minor minerals along with structures and textures were identified using reflected light microscopy in VNIIOkeangeologia. In order to ensure the correct dating of hydrothermal activity episodes, we handpicked, under the binocular, eight samples with $2 \mathrm{~g}$ each of monomineral separates, comprised of individual sulfide minerals (pyrite) or sulfide mineral intergrowth (chalcopyrite-sphalerite, pyrite-sphalerite, pyrite-marcasite), which, according to textural relationships, correspond to isochronous or close to isochronous precipitation. The zonal texture around a fluid conduit and the texture of consequential overgrowth could be an example of such precipitation (Fig. 2B, E).

The detailed mineral composition of all powdered samples were done by X-ray diffraction (XRD) analyses on Rigaku D/MAX 2400 (Cu Ka $35 \mathrm{kV} 25 \mathrm{~mA}$ ), at the "Center of X-ray Diffraction Studies" in the Research Park of St.Petersburg State University, Russia.

The composition of minerals was identified using a Hitachi S3400N scanning electron microscope (SEM) equipped with an energy-dispersive X-ray spectroscopy (EDX) detector AzTec Energy 350 based at the "Center for Geo-Environmental Research and Modeling (GEOMODEL)", Research Park of St. Petersburg State University, Russia, with an acceleration potential of $20 \mathrm{kV}$, a beam current of $2 \mathrm{nA}$ and a spot size that varied from 3-5 $\mu \mathrm{m}$ for the EDX. The thin-sections of sulfide samples were coated with carbon for SEM analysis and imaged using backscattered and secondary electrons (BSE).

Uranium and thorium were radiochemically extracted from the samples by applying the procedure described earlier by Kuznetsov et al. $(2006,2015)$. The specific ${ }^{238} \mathrm{U}$, ${ }^{234} \mathrm{U},{ }^{232} \mathrm{Th}$ and ${ }^{230} \mathrm{Th}$ activities were measured over several days using the alpha-spectrometer "Alpha Duo" (ORTEC). The ${ }^{230} \mathrm{Th} / \mathrm{U}$ age of the samples was calculated by the age equation of Kaufman and Broecker (1965) and given with $1 \sigma$ standard deviation (1):

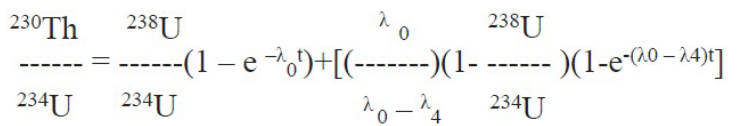

$\lambda_{0}, \lambda_{4}-$ decay constants for the ${ }^{230} \mathrm{Th}$ and ${ }^{234} \mathrm{U} ;{ }^{230} \mathrm{Th} /{ }^{234} \mathrm{U}$ and ${ }^{238} \mathrm{U} /{ }^{234} \mathrm{U}-\mathrm{AR} ;{ }^{234} \mathrm{U},{ }^{238} \mathrm{U},{ }^{230} \mathrm{Th}$ - specific activities; and $t$ - age of a sample

\section{Results}

\subsection{Mineralogy}

Based on the optical and microprobe studies, the massive sulfides are mainly comprised of pyrite, marcasite and chalcopyrite. Minor minerals are represented by pyrrhotite, sphalerite, bornite, covellite and goethite (Table 1).

The textures of overgrowing, massive and zonal crystals are observed (Fig. 2A, B). Some sulfide samples are
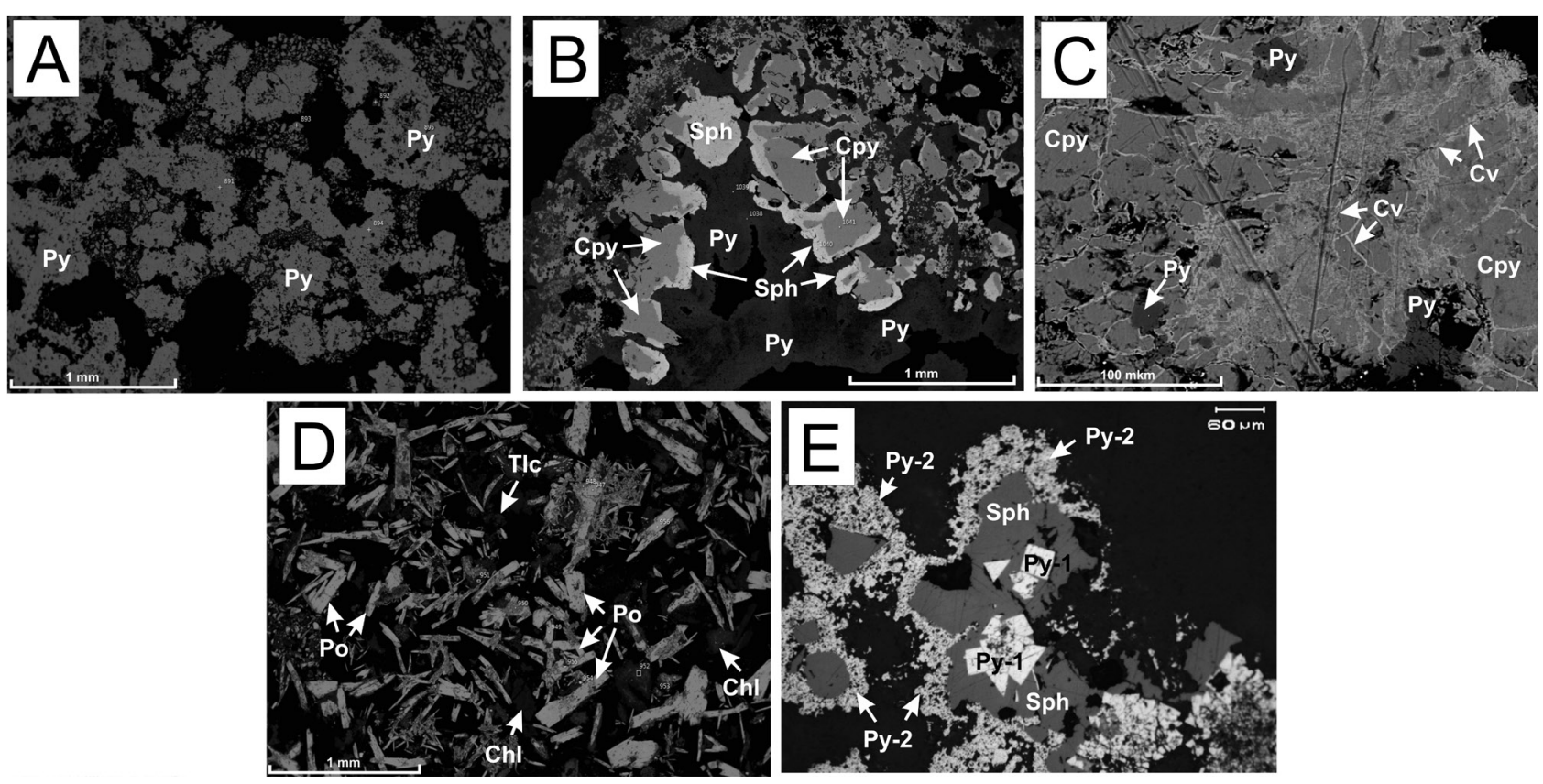

Fig 2. Textural relationships of the major sulfide minerals. A - Porous massive pyrite ores. B-Chalcopyrite and sphalerite intergrowths and late pyrite infilling interstitial space. $C$-Chalcopyrite replaced by late covellite and early pyrite. D-Abundant non-sulfide minerals in the interstitial space of massive sulfide samples. E-Zonal texture around the conduit: sphalerite-pyrite (Py-1) overgrown by fine-grained pyrite (Py-2) showing close to simultaneous precipitation. Py - pyrite, Po-pyrrhotite, Cpy-chalcopyrite, Sph-sphalerite, Cv-covellite, Chl - chlorite, Tlc-talc. 
Table 1. Mineralogical composition of massive sulfides from the Pobeda-1 and -2 hydrothermal fields (XRD analysis).

\begin{tabular}{|c|c|c|}
\hline № field & № sample & Minerals, (\%) \\
\hline \multirow{8}{*}{ Pobeda-1 } & $195-2$ & Pyrite (77.8), marcasite (19.5), aragonite $(<1)$ \\
\hline & $195-3$ & Pyrite (91.8), marcasite (5.2), goethite (3.1) \\
\hline & 196-1-1 & Pyrite (>99) \\
\hline & $196-1$ & Pyrite (63), marcasite $(31)$, aragonite $(<5)$ \\
\hline & $196-2$ & $\begin{array}{l}\text { Pyrite (75.7), marcasite (21.2), pyrrhotite (2.6), } \\
\text { chalcopyrite }(<1)\end{array}$ \\
\hline & $196-3$ & Pyrite (95), goethite (5) \\
\hline & $204-2-1$ & Pyrite (99) \\
\hline & $204-3$ & Pyrite (99.8) \\
\hline \multirow{6}{*}{ Pobeda-2 } & $107-4$ & Chalcopyrite (50), sphalerite (25), pyrite (25) \\
\hline & $107-8$ & Pyrite (87.9), marcasite (9.5), calcite $(<1)$ \\
\hline & $107-10-1$ & Pyrite (99.0), quartz $(<1)$ \\
\hline & $107-11-1$ & $\begin{array}{l}\text { Pyrite (81.1), sphalerite (10.3), chalcopyrite (2.8), } \\
\text { covellite (2.5), calcite (2.5) }\end{array}$ \\
\hline & $107-11-2$ & Pyrite (>99) \\
\hline & $245-3$ & Pyrite (89.9), marcasite (9.6) \\
\hline
\end{tabular}

altered to different degrees. The textures of replacement and alteration were revealed in more than half of the samples, where mineral texture relationships show several stages of precipitation and different generation of minerals (Fig. 2C). In some samples, the presence of non-sulfide minerals (calcite, aragonite, goethite, jarosite, quartz, chlorite, talc) was detected by optical, microprobe and $\mathrm{X}$-ray diffraction analysis (Fig. 2D; Table 1). The samples containing more than $95 \%$ of primary sulfide minerals were chosen for further dating and reconstruction (Fig. 2A and B).

\subsection{Isotopic and dating results}

The results of radiochemical analysis of 10 sulfide samples are compiled in Table 2 . The ${ }^{238} \mathrm{U}$-specific activities of sulfides have a very wide range from $3.615 \pm 0.124 \mathrm{dpm}$ to $9.660 \pm 0.252 \mathrm{dpm}$ (or from 3.085 \pm 2.926 ppm to $92.482 \pm 0.111$ ppm) within the Pobeda-1 and from 0.134 $\pm 0.011 \mathrm{dpm}$ to $113.800 \pm 2.635 \mathrm{dpm}$ (or from $0.751 \pm 0.050$ to $158.056 \pm 3.245$ ppm) within the Pobeda-2 (Table 2).

The specific ${ }^{232} \mathrm{Th}$ activity was very low in the sample $107-8(\leq 0.04 \mathrm{dpm} / \mathrm{g})$ or even below the detection limit in the other samples, which indicates the absence of samples contamination by terrigenous material. Similar results have been obtained for other SMS deposits from the MAR (Lalou et al., 1988, 1996, 1998; You and Bickle 1998; Kuznetsov et al., 2006, 2011, 2015; Kuznetsov and Maksimov, 2012), East Pacific Rise (Lalou and Brichet 1982) and Indian Ridge (Münch et al., 2001; Wang et al., 2012; Yang et al., 2017).

The ${ }^{234} \mathrm{U} /{ }^{238} \mathrm{U}$ activity ratio (AR) obtained varies in the range from $1.113 \pm 0.024$ (sample 196-1-1) to $1.302 \pm 0.135$ (sample 107-4), but most samples are close to the average value of $1.146 \pm 0.002$ in sea waters (Chen et al., 1986). These data indicate the hydrogenous origin of $U$ in the analyzed samples.

Post-depositional input or loss of uranium is relatively difficult to detect. Lalou et al. (1996) presume that the absence of a systematic relationship between the U-specific activity and the sample age from the same hydrothermal cluster gives evidence that closed system conditions with respect to uranium (preventing addition or leaching) prevailed in the sulfide-sea water system. The uranium distribution within the Pobeda hydrothermal cluster (Table 2; Fig. 3) shows that an increase in ${ }^{238} U$ content from the sample 204-2-1 to the sample 196-2 (Pobeda-1) leads to a lowering of the age from ca. $52 \mathrm{kyr}$ to ca. $0.3 \mathrm{kyr}$. On the contrary, increasing of the U-specific activity from the sample 107-8 with age of ca. $4.3 \mathrm{kyr}$ (Pobeda-2) increases the age up to ca. $107 \mathrm{kyr}$ in the sample 107-10-1. Further increase in $U$ concentration in the sample 107-11-1 leads to a decrease of the age to ca. $4.8 \mathrm{kyr}$ in the sample 107 11-1 (Pobeda-2). Moreover, despite the differences in the U content in the samples 196-1, 196-1-1 and 196-2 (Pobeda-1), their ages cluster around ca. $0.3 \mathrm{kyr}$. The lack of a systematic correlation between the U-specific activity and age in the same hydrothermal field or node was confirmed by the previous studies (Lalou et al., 1996; Kuznetsov et al., 2006, 2011, 2015; Kuznetsov and Maksimov, 2012; Wang et al., 2012; Yang et al., 2017). Fig. 3 provides evidence for this statement.

\section{Discussion}

The most reliable result of dating for hydrothermal massive sulfides could be obtained by analyzing minerals corresponding to isochronous or close to isochronous precipitation, i.e. unaltered primary monominerals sulfide phase or sulfide intergrowths precipitating directly from the high/ medium-temperature fluid and sometimes forming the zonal texture.

However, the massive sulfides usually have polymineral composition. The samples could be represented by minerals of one or several generations. The dating of samples composed by one generation minerals gives us correct results. In the case of different generations, the analysis of bulk samples may result in averaging of the age and could not be used for chronological reconstructions.

Another process which results in the distortion of the dating is alteration of primary sulfides and formation of secondary minerals (e.g. bornite, covellite, goethite, jarosite). The presence of secondary minerals might change the initial U- and Th-specific activities, their ${ }^{234} \mathrm{Th} / \mathrm{U}$ AR and distort the dating results (You and Bickle, 1998). In addition, there are non-sulfide minerals related to low-temperature 
Table 2. Results of the radiochemical analyses and 230Th/U ages (both 1 sigma) of the sulfide samples from the Pobeda hydrothermal cluster.

\begin{tabular}{|c|c|c|c|c|c|c|c|}
\hline \multirow{2}{*}{ № sample } & ${ }^{238} \mathrm{U}$ & ${ }^{234} \mathrm{U}$ & ${ }^{230} \mathrm{Th}$ & ${ }^{232} \mathrm{Th}$ & \multirow{2}{*}{${ }^{230} \mathrm{Th} /{ }^{234} \mathrm{U}$} & \multirow{2}{*}{${ }^{234} \mathrm{U} /{ }^{238} \mathrm{U}$} & \multirow{2}{*}{ Age, kyr } \\
\hline & \multicolumn{4}{|c|}{$\mathrm{dpm} / \mathrm{g}^{*}$} & & & \\
\hline \multicolumn{8}{|c|}{ Pobeda-1 } \\
\hline $195-2 * *$ & $10.787 \pm 0.371$ & $12.232 \pm 0.412$ & $2.266 \pm 0.083$ & bdl & $0.185 \pm 0.009$ & $1.134 \pm 0.031$ & $22.1 \pm 1.2$ \\
\hline $195-3^{* *}$ & $30.767 \pm 0.587$ & $35.059 \pm 0.663$ & $4.436 \pm 0.163$ & bdl & $0.127 \pm 0.005$ & $1.140 \pm 0.010$ & $14.6 \pm 0.7$ \\
\hline $196-1$ & $9.660 \pm 0.252$ & $10.909 \pm 0.279$ & $0.033 \pm 0.008$ & bdl & $0.003 \pm 0.001$ & $1.129 \pm 0.023$ & $0.33 \pm 0.08$ \\
\hline $196-1-1$ & $8.113 \pm 0.216$ & $9.033 \pm 0.236$ & $0.022 \pm 0.011$ & bdl & $0.002 \pm 0.001$ & $1.113 \pm 0.024$ & $0.27 \pm 0.13$ \\
\hline $196-2$ & $5.511 \pm 0.133$ & $6.373 \pm 0.149$ & $0.017 \pm 0.006$ & bdl & $0.003 \pm 0.001$ & $1.156 \pm 0.025$ & $0.28 \pm 0.10$ \\
\hline $196-3^{* *}$ & $38.093 \pm 0.970$ & $42.665 \pm 1.079$ & $2.480 \pm 0.075$ & bdl & $0.058 \pm 0.002$ & $1.120 \pm 0.014$ & $6.5 \pm 0.3$ \\
\hline $204-2-1$ & $3.615 \pm 0.124$ & $4.099 \pm 0.136$ & $1.584 \pm 0.076$ & bdl & $0.387 \pm 0.023$ & $1.134 \pm 0.036$ & $52.0 \pm 4.0$ \\
\hline $204-3 * *$ & $3.409 \pm 0.153$ & $4.419 \pm 0.185$ & $1.695 \pm 0.046$ & bdl & $0.384 \pm 0.019$ & $1.296 \pm 0.058$ & $51.4 \pm 3.4$ \\
\hline \multicolumn{8}{|c|}{ Pobeda-2 } \\
\hline $107-4$ & $0.134 \pm 0.011$ & $0.175 \pm 0.013$ & $0.051 \pm 0.008$ & bdl & $0.294 \pm 0.051$ & $1.302 \pm 0.135$ & $37.2 \pm 8.1$ \\
\hline $107-8$ & $4.119 \pm 0.186$ & $5.085 \pm 0.214$ & $0.198 \pm 0.029$ & $0.035 \pm 0.015$ & $0.039 \pm 0.006$ & $1.235 \pm 0.067$ & $4.30 \pm 0.68$ \\
\hline $107-10-1$ & $7.643 \pm 0.240$ & $8.727 \pm 0.269$ & $5.562 \pm 0.236$ & bdl & $0.637 \pm 0.033$ & $1.142 \pm 0.025$ & $107.0 \pm 10.0$ \\
\hline $107-11-1$ & $113.800 \pm 2.635$ & $130.525 \pm 3.014$ & $5.668 \pm 0.138$ & bdl & $0.043 \pm 0.001$ & $1.147 \pm 0.007$ & $4.81 \pm 0.17$ \\
\hline $107-11-2$ & $79.639 \pm 1.710$ & $91.650 \pm 1.961$ & $4.102 \pm 0.114$ & bdl & $0.045 \pm 0.002$ & $1.151 \pm 0.008$ & $4.96 \pm 0.18$ \\
\hline $245-3$ & $10.072 \pm 0.248$ & $11.585 \pm 0.279$ & $0.883 \pm 0.035$ & bdl & $0.076 \pm 0.004$ & $1.150 \pm 0.021$ & $8.59 \pm 0.41$ \\
\hline
\end{tabular}

$\left({ }^{*}\right) \mathrm{dpm}$ - decays per minute per gram, bdl - below detection limit;

$(* *)$ - radioisotope data and age of massive sulfide samples from Gablina et al. 2018.

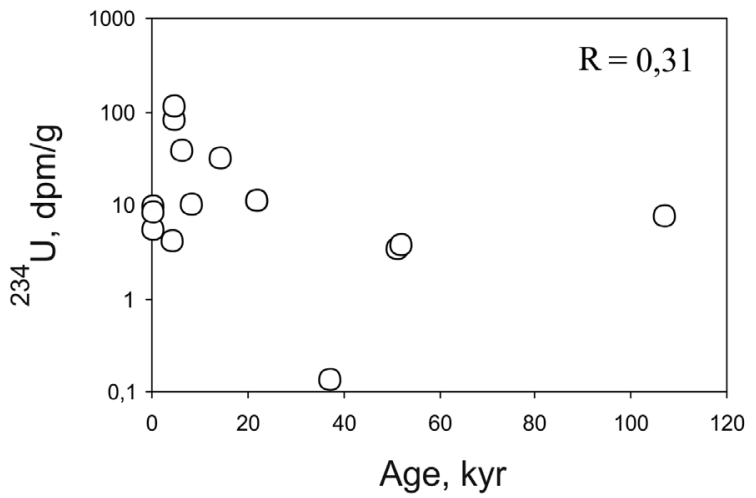

Fig 3. ${ }^{230} \mathrm{Th} / \mathrm{U}$ age vs ${ }^{234} \mathrm{U}$-specific activity for ore samples of the Pobeda sulfide cluster.

hydrothermal precipitates (e.g. calcite, aragonite and barite) or to fragments of altered hosted-rocks (e.g. chlorite) which also could influence the final age as it was already shown in Gablina et al. (2018).

Thus, the chronology should be reconstructed based on the studies of massive sulfide samples preferably comprised of primary sulfide minerals without secondary sulfides and/or non-sulfide minerals. This conclusion could be illustrated by the following age data of bulk and monomineral samples 107-10-1 and 204-2:

- the age of the bulk sample 107-10 composed of different generations of pyrite including older pyrite grains with trace of replacement is around $134.5 \pm 11.4 \mathrm{kyr}$ (Gablina et al.2018), whereas the age of monomineral separates of unaltered younger pyrite (sample 107$10-1$ ) is much lower $-107.0 \pm 10.0 \mathrm{kyr}$ ago;

- the age for the bulk sample 204-2 composed of pyrite, marcasite, chalcopyrite, clinoatacamite and Fe hydroxides is around 113.7 $\pm 9.9 \mathrm{kyr}$ (Gablina et al., 2018); however, the analysis of monomineral separates 204-2-1 represented by unaltered overprinted pyrite gave precipitation age at $52.0 \pm 4.0$ kyr ago.

According to You and Bickle (1998), the ${ }^{234} \mathrm{Th} / \mathrm{U}$ AR in sulfides may be distorted by $U$ being subsequently fixed at oxidation-reduction boundaries of pyrite or lost from this mineral due to alteration process. The last one might have led to increasing of ${ }^{234} \mathrm{Th} / \mathrm{U}$ AR and to older ages of both the analyzed bulk samples. Besides that, the newly crystallizing minerals might have incorporated reworked U or Th from older deposits (You and Bickle, 1998) that can also be a reason for the erroneously old age of bulk samples in our case.

Some of the analyzed samples are characterized by zonal textures:

(1) The samples 204-2-1 and 204-3 are composed of pyrite from the inner and outer parts of a sulfide chimney, respectively. The measured ages of the inner and outer zones demonstrate very close results: $52.0 \pm 4.0 \mathrm{kyr}$ and $51.4 \pm 3.4 \mathrm{kyr}$. 
(2) Analyses of samples composed of pyrite-marcasite intergrowth from the outer part of the chimney (107-11-1) and pyrite-sphalerite intergrowth from the inner part of the same chimney (107-11-2) have shown identical ages within the method uncertainty $-4.81 \pm 0.17$ and $4.96 \pm 0.18$, respectively.

Similar analyses were carried out for samples where mineral composition reflected sequence and close to isochronous precipitation from high- to low-temperature fluid (station 196). The sample 196-1-1 consists of pyrite $(90 \%)$, pyrrhotite $(5 \%)$ and sphalerite $(5 \%)$ formed around $0.27 \pm 0.13 \mathrm{kyr}$, whereas sample 196-2 composed of pyrite $(76 \%)$, marcasite $(21 \%)$ and pyrrhotite $(2.5 \%)$ formed around $0.28 \pm 0.10 \mathrm{kyr}$. Moreover, the age of the bulk sample 196-1 confirmed its precipitation at around $0.33 \pm 0.08$ kyr. Despite the different mineralogical com-

Table 3. The age of massive sulfide from Pobeda hydrothermal cluster.

\begin{tabular}{|c|c|}
\hline № sample & Age, kyr \\
\hline \multicolumn{2}{|c|}{ Pobeda-1 } \\
\hline $195-2^{*}$ & $22.1 \pm 1.2$ \\
\hline $195-3^{*}$ & $14.6 \pm 0.7$ \\
\hline $196-1$ & $0.33 \pm 0.08$ \\
\hline 196-1-1 & $0.27 \pm 0.13$ \\
\hline $196-2$ & $0.28 \pm 0.10$ \\
\hline $196-3^{*}$ & $6.5 \pm 0.3$ \\
\hline 204-2-1 & $52.0 \pm 4.0$ \\
\hline $204-3^{*}$ & $51.4 \pm 3.4$ \\
\hline \multicolumn{2}{|c|}{ Pobeda-2 } \\
\hline $107-4$ & $37.2 \pm 8.1$ \\
\hline $107-8$ & $4.3 \pm 0,7$ \\
\hline $107-10-1$ & $107.0 \pm 10.0$ \\
\hline $107-11-1$ & $4.81 \pm 0.17$ \\
\hline $107-11-2$ & $4.96 \pm 0.18$ \\
\hline $245-3$ & $8.59 \pm 0.41$ \\
\hline
\end{tabular}

Note: the composition of analyzed sample: italic - bulk composition; bold monomineral and sulfide intergrowths; $\left({ }^{*}\right)$ - age of massive sulfide samples from Gablina et al. 2018. position of these samples, the analyzing of textures in the primary unaltered sulfide minerals and intergrowths along with nearly identical age allows us to suggest the isochronous precipitation.

Based on the study of the age in the samples with textures reflecting the close to isochronous precipitation from the same fluid, we conclude that these samples could be analyzed for dating by bulk samples.

Based on the ages of unaltered massive sulfide samples (Table 3), geochronological reconstruction of ore-forming hydrothermal activity was assumed within the Pobeda cluster (Fig. 4).

The age analysis of the massive sulfides shows the oldest age around 52.0 $\pm 4.0 \mathrm{kyr}$ within Pobeda- 1 and 107.0 $\pm 10.0 \mathrm{kyr}$ within Pobeda-2 fields (Fig. 4). Then, the SMS samples/hydrothermal activity are identified at $22.1 \pm 1.2,14.6 \pm 0.7$ and $6.5 \pm 0.3$ up to $0.27 \pm 0.13 \mathrm{kyr}$ within Pobeda-1 field and at $37.2 \pm 8.1$ and $8.59 \pm 0.41 \mathrm{kyr}$ within Pobeda-2. The youngest age of samples from Pobeda- 2 is around $4.96 \pm 0.18$ and $4.3 \pm 0.7 \mathrm{kyr}$.

\section{Conclusion}

According to the conducted study, we conclude that dating of both bulk and monomineral samples could be recommended for the reconstruction of ore-forming hydrothermal activity processes. The bulk samples which are represented by several primary sulfide minerals, which formed zonal, overgrowing and intergrowths texture reflecting the close to isochronous precipitation from the same fluid, could be preferentially used for reconstruction of hydrothermal activity. The samples containing non-sulfide minerals along with texture of replacements, cementing and alteration should be dated in primary monomineral sulfide separates.

This approach for dating along with detailed analysis of mineral relationship and texture/structure of massive sulfides allows us to get correct information about chronology of Pobeda hydrothermal cluster. The ${ }^{230} \mathrm{Th} / \mathrm{U}$ ages obtained for both the bulk samples and monomineral separates combined with data published earlier show the
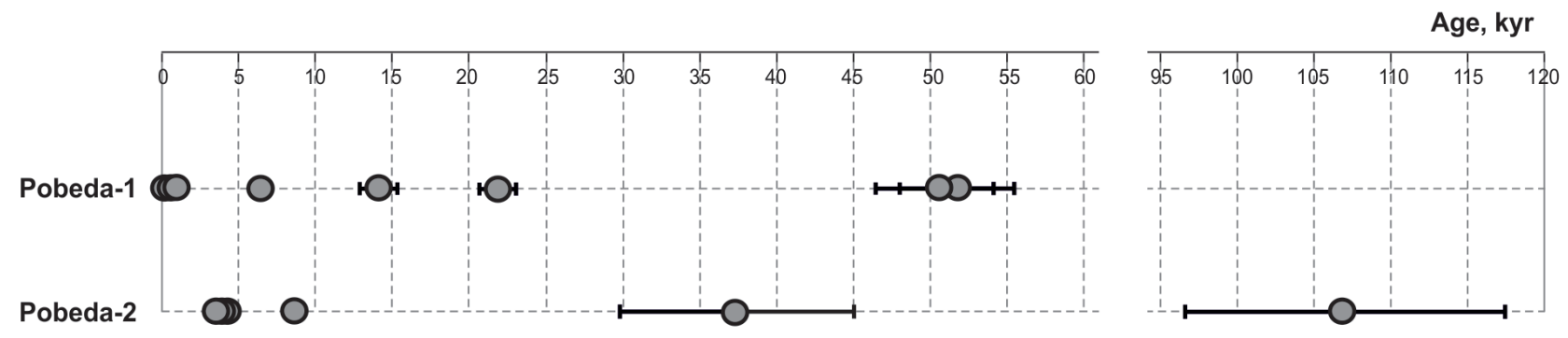

Fig 4. The ages of massive sulfides at Pobeda-1 and Pobeda-2 hydrothermal fields. 
oldest age ca. 52 kyr within Pobeda-1 and ca. 107 kyr within Pobeda-2 fields (Fig. 4). A number of episodes of hydrothermal activity were also identified within Pobeda-1 field up to ca. $0.3 \mathrm{kyr}$ ago and within Pobeda-2 field up to ca. $4.3 \mathrm{kyr}$ ago.

Despite the fact that Pobeda-1 and Pobeda-2 are located only $4 \mathrm{~km}$ apart, the obtained age of massive sulfides and temporal stages of hydrothermal activity are significantly differed. This difference is probably related to unrepresentative sampling of the hydrothermal fields which do not give full information about synchronous events within Pobeda cluster. A more detailed sampling of ore bodies may allow us to improve the study related to this issue.

\section{Acknowledgments}

We would like to thank V. Shylovskykh and N. Vlasenko from the 'Center for Geo-Environmental Research and Modeling (GEOMODEL)', Research Park of St. Petersburg State University (SPSU) for the electron microprobe analysis and the SPSU students, E. Ovsyukov and A. Kovalenko, who participated in the massive sulfide samples treatment. Scientific research was partially performed at the

'Center of X-ray Diffraction Studies' and in the

'Center for Geo-Environmental Research and Modeling (GEOMODEL)', Research Park of SPSU.

The reported study was funded by RFBR according to the research project № 18-05-00861

\section{References}

Amplieva EE, Bortnikov NS, Koval'chuk EV and Beltenev VE, 2017. The Pobeda modern submarine hydrothermal sulfide edifice cluster (Mid-Atlantic Ridge, $17^{\circ} 08^{\prime} \mathrm{N}$ ): mineralogy and chemical composition. Mineral Resources to Discover - 14th SGA Biennial Meeting 2017, S03, 2: 649-652.

Beltenev VYe, Narkevsky EV, Dobretzova IG, Gablina IF, Galkin SV, Molodtsova TN and Laiba AA, 2015. The results of Professor Logatchev-37 cruise, MAR. GEOLOGY OF SEAS AND OCEANS. Proceedings of XXI International Conference on Marine Geology, Moscow, November 16-20, 2: 126-128.

Chen JH, Wasserburg CJ, van Damm KL, and Edmond JM, 1986. The U-Th-Pb systematic in hot springs of the East Pacific Rise at $21 " \mathrm{~N}$ and Guaymas Basin. Geochimica et Cosmochimica Acta 50: 2467-2479, DOI 10.1016/0016-7037(86)90030-X.

Cherkashov G, Kuznetsov V, Kuksa K, Tabuns E, Maksimov F, and Bel'tenev V, 2017. Sulfide geochronology along the Northern Equatorial Mid-Atlantic Ridge. Ore Geology Reviews 87: 147-154, DOI 10.1016/j.oregeorev.2016.10.015.

Gablina IF, Dobretzova IG, Laiba AA, Narkevsky EV, Maksimov FE, and Kuznetsov VYu, 2018. Specific Features of Sulfide Ores in the Pobeda Hydrothermal Cluster, Mid-Atlantic Rise $17^{\circ} 07^{\prime}-$ $17^{\circ} 08^{\prime}$ N. Lithology and Mineral Resources 53(6) 431-454, DOI: 10.1134/S0024490218060020.

Jamieson J, Hannington M, Clague D, Kelley D, Delaney J, Holden J, Tivey M, and Kimpe L, 2013. Sulfide geochronology along the Endeavour Segment of the Juan de Fuca Ridge. Geochemistry Geophysics Geosystems 14: 2084-2099, DOI: 10.1002/ggge.20133.

Kaufman A and Broecker WS, 1965. Comparison of ${ }^{230} \mathrm{Th}$ and ${ }^{14} \mathrm{C}$ ages for carbonates materials from Lakes Lahontan and Bonneville. Journal of Geophysical Research 70: 4030-4042, DOI 10.1029/JZO70i016p04039.

Kuznetsov V, Cherkashev G, Lein A, Shilov V, Maksimov F, Arslanov Kh, Stepanova T, Baranova N, Chernov S and Tarasenko D, 2006. ${ }^{230} \mathrm{Th} / \mathrm{U}$ dating of massive sulfides from the Logatchev and Rainbow hydrothermal fields (Mid-Atlantic Ridge). Geochronometria 25: 51-56.
Kuznetsov V, Maksimov F, Zheleznov A, Cherkashov G, Bel'tenev $\mathrm{V}$ and Lazareva L, 2011. ${ }^{230} \mathrm{Th} / \mathrm{U}$ chronology of ore formation within the Semyenov hydrothermal district $\left(13^{\circ} 31^{\prime}\right.$ N) at the Mid-Atlantic Ridge. Geochronometria 38: 72-76, DOI 10.2478/s13386-011-0001-1.

Kuznetsov VYu and Maksimov FE, 2012. Metody chetvertichnoy geokhronometrii v paleogeografii I morskoy geologii (Methods of Quaternary Geochronometry in Palaeogeography and Marine Geology). Saint-Petersburg, Nauka: 191 (in Russian).

Kuznetsov VYu, Cherkashev GA, Bel'tenev VE, Lein AYu, Maximov FE, Shilov VV and Stepanova TV, 2007. The ${ }^{230} \mathrm{Th} / \mathrm{U}$ dating of sulfide ores in the ocean: Methodical possibilities, measurement results and perspectives of application. Doklady Earth Sciences 417(1): 1202-1205, DOI: 10.1134/ S1028334X07080156.

Kuznetsov V, Tabuns E, Kuksa K, Cherkashov G, Maksimov F, Bel'tenev V, Lazareva L, Zherebtsov I, Grigoriev V, and Baranova $\mathrm{N}, 2015$. The oldest seafloor massive sulphide deposits at the Mid-Atlantic ridge: ${ }^{230} \mathrm{Th} / \mathrm{U}$ chronology and geochemistry. Geochronometria 42: 100-106, DOI: 10.1515/geochr-2015-0009.

Lalou C and Brichet E, 1982. Ages and implications of East Pacific Rise sulphide deposits at $21^{\circ} \mathrm{N}$. Nature 300: $169-171$, DOI: 10.1038/300169a0.

Lalou C, Thompson G, Rona PA, Brichet E and Jehanno C, 1986. Chronology of selected hydrothermal $\mathrm{Mn}$ oxide deposits from the trans-Atlantic geotraverse "TAG" area, Mid-Atlantic Ridge $26^{\circ} \mathrm{N}$. Geochimica et Cosmochimica Acta 50: 1737-1743, DOI 10.1016/0016-7037(86)90135-3.

Lalou C, Reyss JL and Brichet E, 1998. Age of sub-bottom sulfide samples at the TAG active mound. In: Herzig PM., Humphris SE, Miller DJ, Zierenberg RA, Eds., Proceedings of the Ocean Drilling Program, Scientific Results 158: 111-117.

Lalou C, Reyss JL, and Brichet E, 1993. Actinide-series disequilibrium as a tool to establish the chronology of deep-sea hydrothermal activity. Geochimica et Cosmochimica Acta 57: 1221-1231, DOI 10.1016/0016-7037(93)90059-6. 
Lalou C, Reyss JL, Brichet E, Krasnov S, Stepanova T, Cherkashev $\mathrm{G}$, and Markov V, 1996. Initial chronology of a recently discovered hydrothermal field at $14^{\circ} 45^{\prime} \mathrm{N}$, Mid-Atlantic Ridge. Earth and Planetary Science Letters 144: 483-490, DOI 10.1016/ S0012-821X(96)00190-2.

Lalou C, Reyss LG, Brichet E, Krasnov S, Stepanova T, Cherkashev $\mathrm{G}$ and Markov V, 1988. Chronology of a recently discovered hydrothermal field at $14^{\circ} 45^{\prime} \mathrm{N}$, Mid Atlantic Ridge. Earth and Planetary Science Letters 144: 483-490, DOI 10.1016/S0012821X(96)00190-2.

Liang J, Tao C, Yang W, Wang F, Liao S, and Huang W, 2018. ${ }^{230} \mathrm{Th} /{ }^{238} \mathrm{U}$ Dating of Sulfide Chimneys in the Longqi-1 Hydrothermal Field, Southwest Indian Ridge. Acta Geologica Sinica (English Edition), 92(supp.2):77-78, DOI 10.1111/17556724.14202 .
Münch U, Lalou C, Halbach P and Fujimoto H, 2001. Relict hydrothermal events along the super-slow Southwest Indian spreading ridge near 63856XE - mineralogy, chemistry and chronology of sulfide samples. Chemical Geology 177: 341349, DOI 10.1016/S0009-2541(00)00418-6.

Wang Y, Han X, Jin X, Qiu Z, Ma Z and Yang H, 2012. Hydrothermal Activity Events at Kairei Field, Central Indian Ridge $25^{\circ} \mathrm{S}$. Resource Geology 62(2): 208-214, DOI 10.1111/j.17513928.2012.00189.x.

Yang W, Tao C, Li H, Liang J, Liao S, Long J, Ma Z, and Wang L, 2017. ${ }^{230} \mathrm{Th} /{ }^{238} \mathrm{U}$ dating of hydrothermal sulfides from Duanqiao hydrothermal field, Southwest Indian Ridge. Marine Geophysics Resources 38: 71-83, DOI 10.1007/s11001-016-9279-y.

You CF and Bickle M, 1998. Evolution of an active sea-floor massive sulphide deposit. Nature 394: 668-671, DOI 10.1038/29279. 